\title{
PENGARUH SUBSTITUSI PROTEIN TEPUNG PUCUK INDOGOFERA ZOLLINGERIANA DENGAN PROTEIN BUNGKIL KEDELAI DALAM RANSUM TERHADAP ORGAN DALAM BROILER
}

\author{
The Effect Of Indigofera zollingeriana Top Leaf Meal Protein Substitution With Soybean \\ Meal Protein In the diet On giblet of Broilers
}

Melia Afnida Santi

Fakultas Peternakan, Universitas Muhammadiyah Tapanuli Selatan

Email: melia.afnida@um-tapsel.co.id

\begin{abstract}
This research aimed to see the effect of Indigofera Zollingeriana top leaf meal as substitution of soybean meal in the diets on development giblets of broiler chickens. The study was conducted for 35 days and giblets sampling was carried out on the 35 day. The DOC used is the cobs strain produced by PT. Charoen Pokphan Indonesia with an average weight of 35.1 grams. A completely randomized design (CRD) with four treatments and four replications and ten birds in each replication was used in this experiment. Dietary treatments were: R1= diet containing $20 \%$ soybean meal without I. zollingeriana top leaf meal ; R2= diet containing $16 \%$ soybean meal and $5.9 \%$ Indigofera Zollingeriana top leaf meal (substitute $20 \%$ soybean meal protein with Indigofera Zollingeriana top leaf meal) ; R3= diet containing $12 \%$ soybean meal and $11.8 \%$ Indigofera Zollingeriana top leaf meal (substitute $40 \%$ soybean meal protein with Indigofera Zollingeriana top leaf meal); R4= diet containing $8 \%$ soybean meal and $17.74 \%$ Indigofera Zollingeriana top leaf meal (substitute $20 \%$ soybean meal protein with Indigofera Zollingeriana top leaf meal). Variable measured was giblet of broiler (liver, heart, gizzard, spleen, bile, pancreas, kidney, relative length of small intestine and cecum.). The result showed that usage Indigofera Zollingeriana top leaf meal in the diets did not affect giblets of broiler chickens. The conclusion of this study was Indigofera Zollingeriana top leaf meal can be use up to $17.74 \%$ to substitute $60 \%$ soybean meal protein without interrupting the development giblets of broiler.
\end{abstract}

Key words: Broiler Chicken; Indigofera Zollingeriana top leaf meal; Blood profile.

\section{PENDAHULUAN}

Kebutuhan broiler dari tahun ketahun terus mengalami peningkatan. Pertambahan jumlah penduduk mengakibatkan peningkatan terhadap produk peternakan terutama broiler. Sehingga untuk memenuhi permintaan tersebut perlu peningkatan jumlah produksi. Selain itu baru-baru ini impor broiler ke Indonesia bisa dibilang tinggi, karena boiler yang di datangkan ke Indonesia memiliki harga yang lebih rendah dibandingkan dengan broiler yang di produksi di Indonesia. Tingginya harga broiler di Indonesia disebabkan karena tingginya biaya produksi yang di keluarkan peternak, salah satunya adalah biaya pakan. 
Karena dalam produksi broiler $70 \%$ nya di pengaruhi oleh biaya pakan. Tingginya biaya pakan ini disebabkan karena tingginya harga bahan pakan di pasaran, sehingga meningkatkan biaya produksi perekor ternaknya. Bahan pakan berupa sumber protein di Indonesia masih bergantung kepada Import salah satunya adalah bungkil kedelai. Maka dari itu perlu adanya bahan pakan sumber protein yang dapat mengurangi penggunaaan bungkil kedelai dalam ransum sehingga dapat mengurangi biaya produksi.

Indogifera zollingeriana adalah salah satu tanaman leguminosa yang memiliki kandungan protein yang tinggi $28.41 \%$ (Santi, 2015), beberapa penelitian terdahulu juga sudah melaporkan mengenai kandungan protein daun Indigofera ini seperti Abdullah (2010) menyatakan kandungan protein Indigofera adalah $27.68 \%$, kemudian Akbarillah et al (2008) menyebutkan kandungan protein indigofera adalah $27.89 \%$. Kandungan protein yang tinggi pada Indigofera dapat di jadikan sebagai subtitusi proein bungkil kedelai sehingga penggunaan bungkil kedelai dalam ransum broiler dapat dikurangi sehingga biaya produksi jadi lebih rendah. Selain itu Indigofera dapat dibudidayakan di setiap daerah Indonesia sehingga ketersediaanya dapat berkesinambungan. Selain kandungan proteinnya yang tinggi Indigofera memiliki banyak keunggulan salah satunya adalah adanya kandungan antioksidan seperti pigmen xantophyl dan karatenoid.

Kandungan karatenoid yang terdapat didalam ransum dapat dijadikan sebagai feed additive sehingga meningkatkan kualitas ransum dan dapat memacu pertumbuhan broiler. Palupi et al (2014) telah melakukan kajian tentang penggunaan indigofera untuk unggas, yaitunnya penggunaan Indigofera sebanyak $15.6 \%$ sebagai substitusi $45 \%$ bungkil kedelai meningkatkan produksi telur sebayak 11\%. Santi et al., (2015) melaporkan bahwa penggunaan Indigofera dalam ransum broiler sebanyak $17.74 \%$ sebagai substitusi $60 \%$ protein bungkil kedelai meningkatkan bobot badan boiler dan menurunkan kandungan MDA daging serta dapat menurunkan kandungan lemak dan kolesterol pada broiler.

Melihat potensi yang dimilki oleh Indigofera perlu dilakukan kajian tentang penggunaan Indigofera dalam ransum terhadap bobot relatif organ dalam broiler. Karena organ dalam ini menggambarkan seberapa keras kerja organ dalam mencerna bahan pakan. Serta untuk melihat fungsi dari organ tersebut. Kandungan antinutrisi yang terdapat di dalam pakan akan menggangu 
fungsi organ dan dapat menyebabaan ketidak normalan ukuran bahkan fungsi organ. Jadi dengan adanya Indigofera di dalam ransum apakah nantinya akan mengganggu fungsi organ broiler.

\section{MATERI DAN METODE}

Rancangan yang digunakan dalam penelitian dalam penelitian adalah rancangan acak lengkap dengan 4 perlakuan dan 4 ulangan yang terdiri dari 10 ekor ayam setiap ulangan. Pemeliharaan dilakukan dalam kangang dengan ukuran $1.5 \mathrm{~m}$ x $1.5 \mathrm{~m}$ yang masing-masingnya dilengkapi dengan pemanas, tempat pakan dan tempat minum . Pemeliharaan dilakukan selama 35 hari dan pakan peralakuan diberikan mulai dari ayam berumur 2 minggu sampai dengan 5 minggu. DOC yang dipakai adalah strain cobb yang di produksi oleh PT. Charoen Pokhan Indonesia dengan bobot rata-rata DOC adalah 35.1 gram. Bahan yang digunakan dalam menyusun ransum adalah jagung kuning, dedak padi, Corn Gluten Meal (CGM), bungkil kedelai, tepung pucuk Indigofera, tepung ikan, minyak sawit, dicalsium phospat (DCP), $\mathrm{CaCo}_{3}$, garam, premix, L-Lysine, dan DL-methionin. Ransum perlakuan disusun berdasarkan Lesson and Summer (2008) dengan kandungan nutrien ransum masingmasing perlakuan disajikan pada Tabel 1 .
Tabel 1. Kandungan nutrien ransum masingmasing perlakuan

\begin{tabular}{lcccc}
\hline Kandungan Nutrien & $\mathrm{R} 1$ & $\mathrm{R} 2$ & $\mathrm{R} 3$ & $\mathrm{R} 4$ \\
\hline EM (kkal kg-1) & 3101.08 & 3105.45 & 3101.20 & 3101.13 \\
Protein (\%) & 20.02 & 20.02 & 20.01 & 20.02 \\
Lemak (\%) & 5.25 & 5.52 & 5.74 & 6.13 \\
SK (\%) & 2.98 & 3.36 & 3.78 & 4.23 \\
Lisin (\%) & 1.13 & 1.13 & 1.12 & 1.11 \\
Metionin (\%) & 0.55 & 0.58 & 0.55 & 0.57 \\
Meth+ sistin (\%) & 0.88 & 0.88 & 0.82 & 0.82 \\
Kalsium (\%) & 0.92 & 0.91 & 0.93 & 0.91 \\
Pospor tersedia (\%) & 0.45 & 0.46 & 0.47 & 0.46 \\
Sodium (\%) & 0.12 & 0.11 & 0.11 & 0.11 \\
Chloride (\%) & 0.14 & 0.14 & 0.14 & 0.14 \\
\hline
\end{tabular}

Perlakuan pakan dengan substitusi protein bungkil kedelai dengan protein indigofera adalah sebagai berikut: $\mathrm{R} 1=$ Ransum mengandung 20\% bungkil kedelai (BK) tanpa tepung pucuk Indigoferra Zollingeriana (TPI); $\quad \mathrm{R} 2=\quad$ Ransum mengandung $16 \%$ BK dan $5,9 \%$ TPI (substitusi $20 \%$ protein BK oleh protein TPI); $\mathrm{R} 3=$ Ransum mengandung 12\% BK dan 11,8\% TPI (substitusi 40\% protein BK oleh protein TPI); R4= Ransum mengandung $8 \%$ BK dan $17,74 \%$ TPI (substitusi $60 \%$ protein BK oleh protein TPI. Parameter yang diukur adalah bobo relatif giblet broiler (bobot relatif hati, jantung, rempela, limpa, pancreas, empedu, ginjal, panjang relaif usus dan panjang relatif sekum). 


\section{Analisis data}

Data yang diperoleh dianalisis dengan menggunakan sidik ragam (Analysis of Variance) pada taraf 5\% dan hasil analisis yang menunjukkan pengaruh yang nyata dilajutkan dengan uji Duncan 's Multiple Range Test (Steel dan Torrie 1995). Analisis data dilakukan dengan menggunakan program IBM SPSS V21.

\section{HASIL DAN PEMBAHASAN}

Pertumbuhan bobot badan broiler dipengaruhi oleh pakan yang dikonsumsi oleh ternak tersebut. Kandungan nutrien yang terdapat di dalam pakan akan mempengaruhi fungsi dari organ pencernaan seperti adanya antinutrisi yang terdapat di dalam pakan akan menghambat aktifitas pencernaan sehingga pencernaan tidak maksimal dan akan mempengaruhi bobot masing-masing organ pencernaan. Rataan bobot relatif organ dalam penelitian disajikan pada Tabel 2.

\begin{tabular}{|c|c|c|c|c|c|}
\hline \multirow[t]{2}{*}{ Peubah } & \multicolumn{4}{|c|}{ Perlakuan } & \multirow{2}{*}{$\begin{array}{l}\text { Standar } \\
\text { normal }\end{array}$} \\
\hline & R1 & $\mathrm{R} 2$ & R3 & R4 & \\
\hline Hati (\%) & $2.84 \pm 0.32$ & $2.81 \pm 0.40$ & $2.51 \pm 0.04$ & $3.02 \pm 0.18$ & $2.64-3.3^{1}$ \\
\hline Jantung (\%) & $0.51 \pm 0.07$ & $0.52 \pm 0.04$ & $0.51 \pm 0.10$ & $0.56 \pm 0.03$ & $0.42-0.70^{1}$ \\
\hline Rempela (\%) & $1.34 \pm 0.18$ & $1.40 \pm 0.09$ & $1.50 \pm 0.19$ & $1.50 \pm 0.12$ & $1.6-2.3^{2}$ \\
\hline Limpa $(\%)$ & $0.11 \pm 0.02$ & $0.12 \pm 0.03$ & $0.10 \pm 0.01$ & $0.12 \pm 0.01$ & $0.10-0.11^{3}$ \\
\hline Pankreas $(\%)$ & $0.29 \pm 0.03$ & $0.24 \pm 0.02$ & $0.26 \pm 0.03$ & $0.28 \pm 0.04$ & $0.25-0.40^{2}$ \\
\hline Empedu (\%) & $0.08 \pm 0.02$ & $0.11 \pm 0.04$ & $0.12 \pm 0.02$ & $0.12 \pm 0.02$ & $0.09-0.15^{4}$ \\
\hline Ginjal (\%) & $0.65 \pm 0.06$ & $0.69 \pm 0.03$ & $0.71 \pm 0.04$ & $0.75 \pm 0.12$ & $0.43-0.84^{4}$ \\
\hline Panjang relatif usus (cm 100g BB-1) & $12.84 \pm 0.43$ & $12.35 \pm 0.53$ & $12.82 \pm 1.15$ & $12.95 \pm 0.68$ & $17.13-19.80^{4}$ \\
\hline Panjang relatif sekum (cm 100g BB-1) & $1.21 \pm 0.05$ & $1.41 \pm 0.05$ & $1.30 \pm 0.20$ & $1.32 \pm 0.09$ & - \\
\hline
\end{tabular}

Keterangan: : ${ }^{1}$ Putnam (1991), ${ }^{2}$ Sturkie (2000), ${ }^{3}$ Nkukwana (2014), ${ }^{4}$ Hermana et al., (2005).

Bobot relatif organ dalam pada penelitian berada pada kisaran normal bobot organ broiler umur 5 minggu. Hasil analisis statistik menunjukkan bahwa perlakuan (sustitusi tepung pucuk indigofera dengan bungkil kedelai) tidak berpengaruh nyata terhadap bobot relatif organ dalam broiler. Bobot organ dipengaruhi oleh fungsi dari organ tersebut, tidak adanya pengaruh perlakuan terhadap organ dalam ini menunujukkan bahwa semua organ bekerja dalam fungsi yang normal. Artinya tidak terdapatnya zat antinutrisi yang dapat menghambat kerja organ sehingga pertumbuhan organ normal dan masih berada dalam batas standar masing-masing. Yang berfungi untuk detoksifikasi racun di dalam tubuh adalah fungsi dari hati. Apabila 
terdapat racun di dalam pakan akan mempengaruhi bobot hati yang dapat ditunjukkan dengan pengecilan maupun pembesaran hati (Ressang 1984).

Begitu juga halnya dengan bobot jantung. Bobot jantung pada penelitian berada dalam standar normal. Jantung ini berfungsi untuk memompakan darah untuk menyokong proses metabolisme dalam tubuh. Jantung dapat mengalami pembesaran akibat adanya akumulasi racun pada otot jantung tersebut, dari sini dapat dilihat bahwa indigofera dalam ransum sebagai subtitusi bungkil kedelai tidak menghambat kerja organ terutama jantung. Hal ini menunjukkan bahwa indigofera tidak mengandung antinutrisi yang dapat merugikan ternak. Kandungan serat kasar tepung pucuk indigofera didalam ransum masih berada dalam batasan normal toleransi untuk broiler. Hal ini dapat dilihat pada bobot relatif rempela yang dihasilkan pada penelitian. Serat kasar yang terdapat dalam tepung pucuk indigofera masih dapat dicerna oleh broiler sehingga tidak memperbesar bobot rempela, karena bobot dari remppela dipengaruhi oleh kandungan serat kasar ransum. Semakin tinggi kadar serat kasar yang terdapat di dalam ransum akan meningkatkan bobot rempela, karena aktifitas rempela menjadi meningkat. Begitu juga terhadap panjang relaif usus halus dan sekum. Ini juga dipengaruhi oleh kadar serat kasar ransum. Semakin tinggi kadar serat kasar dapat mengakibatkan laju pencernaan dan absorbsi zat makanan jadi semakin lambat. Begitu juga untuk bobot organ yang lainnya seperti limfa, pancreas, empedu, dan ginjal semuanya berada dalam bobot yang relatif normal. Secara keseluruhan substitusi protein bungkil kedelai dengan protein tepung pucuk indigofera tidak mengganggu perkembangan organ dalam broiler.

\section{KESIMPULAN}

Dari hasil penelitian dapat disimpulkan bahwa tepung pucuk indigofera dapat digunakan di dalam ransum sebayak $17.74 \%$ sebagai subtitusi protein bungkil kedelai sebanyak $60 \%$ tanpa mengganggu organ dalam broiler tersebut.

\section{DAFTAR PUSTAKA}

Abdullah L. 2010. Herbage production and quality of shrub indigofera treated by different concentration of foliar fertilizer. Media Petern. 33 (3): 169175.

Akbarillah T, Kususiyah, Kaharuddin D, Hidayat. 2008. Kajian tepung Daun indigofera sebagai suplemen pakan terhadap produksi dan kualitas telur puyuh. JSPI. 3(1):20-23. 
Hermana W, Puspitasari DI, Wiryawan KG, Suharti S. 2005. Pemberian tepung daun salam (Syzygium polyanthum (wight) walp.) dalam ransum sebagai bahan antibakteri Escherichia coli terhadap organ dalam ayam broiler. Media Petern. 31(1): 63-70.

Nkukwana TT, Muchenje V, Pieterse E, Masik PJ, Mabusela TP, Hoffman LC, Dzama K. 2014. Effect of Moringa oleifera leaf mealon growth performance, apparent digestibility, digestive organsize and carcass yield in broiler chickens. Livestock Science. 161: 139-146.

Leeson S, Summers JD. 2008. Commercial Poultry Nutrition.3rd Ed. Departement of Animal and Poultry Science, University Guelph.University Books. Canada.

Palupi R, Abdullah L, Astuti DA, Sumiati. 2014b. High antioksidan egg production through subsitution of soybean meal by indigofera $s p$ top leaf meal in laying hen diets. Inter $J$ of Polt Scien. 13(4):198-203.

Putnam PA. 1991. Handbook of Animal Science. Saan Diego. Academic Pr.

Ressang AA. 1984. Patologi Khusus Veteriner. Edisi kedua. Denpasar. NV Percetakan Bali.

Santi, MA, Sumiati, Abdullah L. 2015. Cholesterol and Malondialdehyde Contents of Broiler-Chicken Meat Supplemented with Indigofera zolingeriana Top Leaf Meal. Med.Pet. 38 (3):163-168.

Steel RGD, Torrie JH. 1995. Prinsip Dan Prosedur Statistika. Penterjemah
Bambang Sumantri, penerjemah. Jakarta (ID): Gramedia Pustaka.

Sturkie PD. 2000. Avian Physiology. New York (ID). Spinger-Verlag. 